\title{
11- Türkçenin yabancı dil olarak öğretiminde öğrenen ihtiyaçlarının belirlenmesine ilişkin yapılan çalışmalar üzerine bir değerlendirme
}

Eda KİBAR'

APA: Kibar, E. (2021). Türkçenin yabancı dil olarak öğretiminde öğrenen ihtiyaçlarının belirlenmesine ilişkin yapılan çalışmalar üzerine bir değerlendirme. RumeliDE Dil ve Edebiyat Araştırmaları Dergisi, (Ö10), 180-191. DOI: 10.29000/rumelide.1009059.

\section{$\ddot{\mathbf{O} z}$}

Türkçe, yurt içinde ve yurt dışında yabancı dil olarak öğretilmektedir. Öğrenenlerin eğitim ortamlarına etkin olarak katılımlarının sağlanması için öğrenen ihtiyaçlarının belirlenmesi oldukça önemlidir. Yabancı dil öğrenme bağlamında ihtiyaçların belirlenmesi, öğrenenlerin tercihleri ve ihtiyaçları hakkında sistematik olarak bilgi toplama, bilgileri yorumlama ve sonrasında bu ihtiyaçları karşlamaya yönelik karar verme sürecidir. İhtiyaç analizi, derslerin düzenlenmesinde ilk adımdır. $\mathrm{Bu}$ araştırmanın temel amacı da Türkçenin yabancı dil olarak öğretiminde öğrenen ihtiyaçlarının belirlenmesine ilişkin alan yazındaki çalışmaların incelenip bir araya toplanması; bu ihtiyaçların ülkelere göre hangi alt boyutlarda yoğunlaştı̆̆ının tespit edilmesidir. Alan yazında Türkçenin yabancı dil olarak öğretiminde öğrenen ihtiyaçlarının analizi konusunun ele alındığı 2012- 2019 yılları arasında hazırlanmış 9 makale ve 4 yüksek lisans tezi araştırma kapsamına dahil edilmiştir. Tarama yapılırken GOOGLE SCHOLAR veri tabanı kullanılmıştır. Araştırmaya dahil edilen 13 çalışmanın incelenmesi için nitel araştırma desenlerinden doküman incelemesi yöntemi kullanılmıştır. Çalışmalarda toplanan veriler içerik analizi yöntemi kullanılarak incelenmiştir. Araştırma alan yazında bu konuda yapılmış 13 çalışmadan elde edilen veriler ile sınırlandırılmıştır. Elde edilen veriler değerlendirildiğinde 10 ülke (Bosna-Hersek, Kosova, İran, Polonya, Gürcistan, Türkiye, Mısır, Afganistan, Hindistan, Cibuti) üzerine ihtiyaç analizi araştırması yapıldığı görülmüştür. Araştırma yapılan ülkelerde Türkçeyi yabancı dil olarak öğrenenlerin dil ihtiyaçlarının ülkelere göre farklı alt boyutlarda yoğunlaştığı tespit edilmiştir. Yapılan çalışmaların yayın yılına bakıldığında $2012-2019$ yılları arasında yapıldıkları görülmüştür.

Anahtar kelimeler: Türkçenin yabancı dil olarak öğretimi, dil ihtiyaç analizi, dil öğretimi

\section{An evaluation on the studies on determining the needs of learners in teaching Turkish as a foreign language}

\begin{abstract}
Turkish is taught as a foreign language in Turkey and abroad. It is quite important to identify learner needs in order to enable learners to participate effectively in educational environment. Identifying needs in the context of foreign language learning is the process of systematically collecting information about learners' preferences and needs, interpreting the information, and then making decisions to meet these needs. Needs analysis is the first step in organizing lessons. The main purpose of this research is to examine and gather the studies in the literature on the determination of learner needs in teaching Turkish as a foreign language; It is to determine in which sub-dimensions these needs are concentrated according to the countries. In the literature, 9 articles and 4 master's theses,
\end{abstract}

YL, İstanbul Aydın Üniversitesi, Türkçe Eğitimi ABD (İstanbul, Türkiye), edakibar@stu.aydin.edu.tr, ORCID ID: oooooo01-5384-730X [Araştırma makalesi, Makale kayit tarihi: 25.09.2021-kabul tarihi: 20.10.2021; DOI: 10.29000/rumelide.1009059]

RumeliDE Dil ve Edebiyat Araştrmalar Dergisi Osmanağa Mahallesi, Mürver Çiçeği Sokak, No:14/8 Kadıköy - İSTANBUL / TÜRKIYE 34714 e-posta: editor@rumelide.com tel: +90 $5057958124,+902167730616$

Address

RumeliDE Journal of Language and Literature Studies Osmanağa Mahallesi, Mürver Çiçeği Sokak, No:14/8

Kadıköy - ISTANBUL / TURKEY 34714

e-mail: editor@rumelide.com,

phone: +90 $5057958124,+902167730616$ 
which were prepared between 2012 and 2019, on the analysis of learner needs in teaching Turkish as a foreign language, are included in the scope of the research. GOOGLE SCHOLAR database is used while scanning. The method of document examination from qualitative research patterns is used to examine the 13 studies included in the study. The data collected in the studies are analyzed by using the content analysis method. The research is limited to the data obtained from 13 studies on this subject in the literature. When the obtained data are evaluated, it is seen that a needs analysis research are conducted on 10 countries (Bosnia-Herzegovina, Kosovo, Iran, Poland, Georgia, Turkey, Egypt, Afghanistan, India, Djibouti). It has been determined that the language needs of those who learn Turkish as a foreign language in the researched countries are concentrated in different subdimensions according to the countries. Considering the publication year of the studies, it is seen that they were carried out between 2012 and 2019.

Keywords: Teaching Turkish as a foreign language, language needs analysis, language teaching

\section{Giriş}

Günümüzde toplumlar arası kültürel, siyasi ve ekonomik ilişkilerin zamanla gelişmesi sonucunda yabancı dil öğrenme ihtiyacı ortaya çıkmıştır. Toplumlar arası iletişimin temelini oluşturan yabancı dil öğrenme ihtiyacı, geçmişten günümüze giderek artmaktadır (Boylu, 2020, s.87). Demir (2010), toplumların tarih boyunca yabancı dil öğretimi yaptıklarını ifade etmiştir. İnsanlar kültür, bilim, ekonomi, sanat, eğitim gibi pek çok çeşitli sebepten dolayı yabancı dil öğrenmeye ihtiyaç duymuştur (Akt: Tok ve Yıgın, 2013, s.133).

Arapçadan Türkçeye geçen "ihtiyaç" kelimesi, Türk Dil Kurumu tarafından "güçlü istek, yoksunluk, gereksinim, gereksinilen şey” olarak tanımlanmaktadır. İhtiyaçlar, bireyler için itici bir güç rolünü üstlendiği ve onlara gereksinimlerini karşlamaları adına sunulan her türlü olanak, motivasyon aracı olabildiği (Güven vd., 2005) için dil öğretiminde önemli bir yere sahiptir. Bunun için dil öğretimi planlanırken ihtiyaç analizi çalışmalarından yararlanılmaktadır (İpek ve Çelik, 2019).

İhtiyaç analizi kavramının ilk olarak Michael West tarafından 1920'li yıllarda öğrencilerin niçin ve nasıl İngilizce öğrenmeleri gerektiğini açıklamak için Hindistan'da kullanıldığı ama 1970’lere kadar çok ilgi görmediği ifade edilir. Avrupa Konseyi’nin dil öğretimi alanında yaptığı çalışmalar sonucunda bu kavram 1970'li yıllarda popülerlik kazanmıştır. West'e (1997) göre ilk zamanlarda ihtiyaç analizinin amacı hangi becerilerin ve hangi görevlerin daha önemli olduğunu tespit etmekti. İkinci aşamada öğrencilerin mevcut dil yeterliliği ile hedef dil arasındaki mesafeyi ölçen "eksiklik analizini” kapsayacak şekilde genişletilmiştir. Son aşamada ise ihtiyaç analizi öğrencilerin mevcut dil eksiklikleri, istekleri, beklentileri, öğrenme tercihleri ve stratejileri gibi kavramları içerisine alarak daha da genişlemiştir (Demir, 2017)

Graves'e göre (2000) yabancı dil öğrenme bağlamında, ihtiyaç analizi, öğrenenleri tercihleri ve ihtiyaçları hakkında sistematik olarak bilgi toplama, bilgileri yorumlama ve sonrasında bu ihtiyaçları karşılamaya yönelik karar verme sürecidir. İhtiyaç analizi, derslerin düzenlenmesinde ilk adımdır. İhtiyaç analizinin amacı, derslerin nasıl düzenlenmesi gerektiği hakkında bilgi vermektedir (Johns, 1991) (Akt. Çalışkan ve Çangal, 2013:311).

İhtiyaç analizi, Taba-Tylar’ın program geliştirme modelinde birinci basamağı oluşturmaktadır. Etkin bir öğretim programı için öğrenen ihtiyaçlarının saptanması büyük bir öneme sahiptir. İhtiyaç analizi

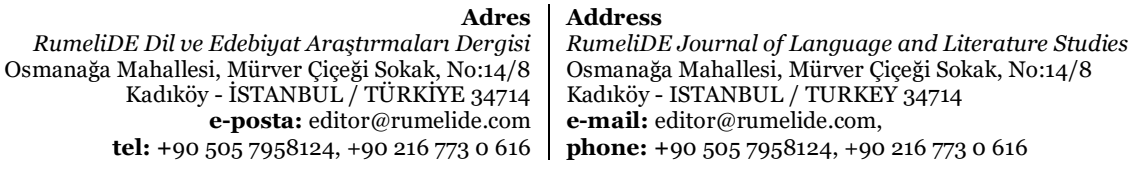


öğretimin hedeflenen noktaya ulaşıp ulaşmadığını tespit etmek için de önemlidir. İhtiyaçlar belirlenirken toplumun, bireyin ve konu alanının ihtiyaçları da göz önüne alınmalıdır (Demirel, 2011, s.74-75). Bunu için ihtiyaç analizi yaparken öğrenci görüşlerinin yanında veli ve öğretmen görüşleri de bu sürece ışık tutabilmektedir.

Dil öğretiminin tam anlamıyla gerçekleşebilmesi için öğrenicilerin dil öğrenme ihtiyaçlarının karşılanması gerekmektedir. Öğrenenlerin dil öğrenme ihtiyaçları dikkate alınmadan gerçekleştirilen bir dil öğretiminde, öğrenenleri farkında olmadan o dille çatışmaya götürebiliriz. Bu sebeple dil öğretiminde öğrenen ihtiyaçları göz önünde bulundurulmalıdır. "Kime ve Nasıl? öğretilecek sorularına verilecek cevaplar bize dil öğretiminde öğrenenlerin ihtiyaçlarını verecektir (İşcan vd., 2013, s.1187).

\subsection{Araştırmanın amacı}

$\mathrm{Bu}$ araştırmanın temel amacı Türkçenin yabancı dil olarak öğretiminde öğrenen ihtiyaçlarının belirlenmesine ilişkin alan yazındaki çalışmaların bir araya toplanıp değerlendirilmesidir. Bu amaç doğrultusunda araştırmanın temel problemi şudur:

"Türkçenin yabancı dil olarak öğretiminde öğrenen ihtiyaçlarının tespitine ilişkin yapılan çalışmalarda öğrenenlerin dil öğrenme ihtiyaçları hangi alt boyutlarda yoğunlaşmaktadır?”

Araştırmada, bu temel problem cümlesinin cevabını bulabilmek için aşağıdaki alt sorulara yanıt aranmıştır:

Türkçenin yabancı dil olarak öğretilmesinde öğrenen ihtiyaçları tespiti çalışmalarının;

1. Araştırma türlerine göre dağılımı nasıldır?

2. Yıllara göre dağılımı nasıldır?

3. Hedef ülkelere göre ihtiyaç dağılımı nasıldır?

4. Yöntem (örneklem büyüklüğü, veri toplama araçları, veri analiz) bölümlerinin tasarımı nasıldır?

\subsection{Araştırmanın önemi}

Yabancı dil olarak Türkçe öğretiminde, öğrenen ihtiyaçlarını belirlenmesi, öğrenicilerin eğitim ortamına etkin katılımlarını sağlamak açısından önemlidir. Öğretimde başarııı arttıracak en önemli etken ise öğrenenlerin ihtiyaç analizinin yapılması ve ortaya çıkan sonuçlardan hareketle ihtiyaçları göz önünde bulundurarak öğretim programlarının düzenlenmesidir. Etkin bir öğretim programı oluşturmanın ilk basamağını ihtiyaç analizi oluşturmaktadır (İşcan vd., 2013, s.1185).

Ülkelere göre yabancı dil olarak Türkçe öğrenicilerinin dil öğrenme amaçları farklılaşmaktadır. Bundan dolayı bu araştırma, Türkçenin yabancı dil olarak öğretilmesi konusunda alan yazına katkı sağlaması ve Türkçenin yabancı dil olarak öğretiminde öğrenen ihtiyaçlarının belirlenmesine ilişkin yapılan çalışmaların tek bir çalışma altında değerlendirilmesi bakımından önemlidir. Bu bağlamda araştırmanın Türkçenin yabancı dil olarak öğretiminde karşılaşılabilecek sorunları en aza indirgenmesine yardımcı olacağı düşünülmektedir.

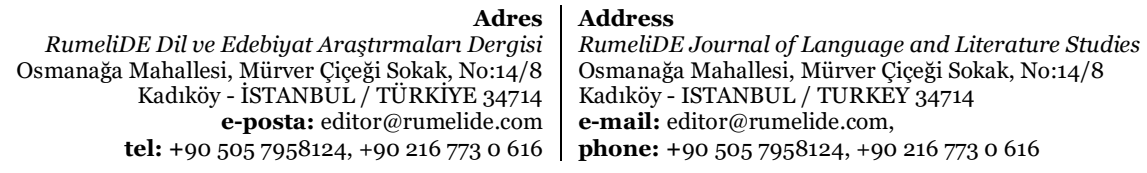




\section{Yöntem}

\subsection{Araştırmanın modeli}

Araştırmada Türkçenin yabancı dil olarak öğretiminde öğrenen ihtiyaçlarının belirlenmesine yönelik yapılan alan yazındaki çalışmaları incelenmek amaçlandığından nitel araştırma desenlerinden doküman incelemesi yöntemi kullanılmıştır. Doküman incelemesi; araştırılması hedeflenen olgu veya olgular hakkında bilgi içeren yazılı materyallerin analizini kapsamaktadır. Doküman analizi, araştırma verilerinin birincil kaynağı olarak çeşitli dokümanların toplanması, gözden geçirilmesi, sorgulanması ve analizi olarak tanımlanabilen bilimsel bir araştırma yöntemidir (Sak vd., 2021, s.230). Bu yöntem, alan yazında çoğunlukla diğer araştırma yöntemlerinin tamamlayıcısı olarak hizmet ederken, tek başına bir yöntem olarak da kullanılmaktadır. Bu yöntemde var olan kayıt ve belgeler incelenerek veriler elde edilir.

\subsection{Verilerin toplanmasi}

Araştırmada veri toplama aracı olarak alan yazında Türkçenin yabancı dil olarak öğretiminde öğrenen ihtiyaçlarının analizi konusunun ele alındığı 2012- 2019 yılları arasında hazırlanmış toplam 9 makale ve 4 yüksek lisans tezi araştırmaya dahil edilmiştir. Tarama yapılırken GOOGLE SCHOLAR ve Ulusal Tez Merkezinin veri tabanı kullanılmıştır.

\subsection{Verilerin analizi}

Araştırmada verileri analiz etmek için betimsel analiz kullanılmıştır. Yıldırım ve Şimşek'e (2016) göre betimsel analizin temel amacı elde edilen bulguları düzenlenmiş ve yorumlanmış bir şekilde okuyucuya sunmaktır. Bu amaç doğrultusunda elde edilen veriler sistematik ve açık bir şekilde betimlenir. Sonrasında bu betimlemeler açıklanarak yorumlanır ve bazı sonuçlara ulaşılır.

\section{Bulgular}

Bu bölümde Türkçenin yabancı dil olarak öğretiminde öğrenen ihtiyaçlarının belirlenmesine ilişkin yapılan 13 araştırma; türü, yayın yılı, dil ihtiyaçlarının ülkelere göre hangi alt boyutlarda yoğunlaştığı, örneklem büyüklüğü, veri toplama araçları, bulguları ve veri analiz teknikleri açısından incelenmiştir.

\section{1. Çalışmaların “Araştırma türlerine göre dağılımı nasıldır?” sorusuna ilişkin bulgular}

Aşağıda Türkçenin yabancı dil olarak öğretilmesinde öğrenen ihtiyaçları tespiti çalışmalarının araştırma türlerine göre dağılımlarına ait bilgiler verilmiştir.

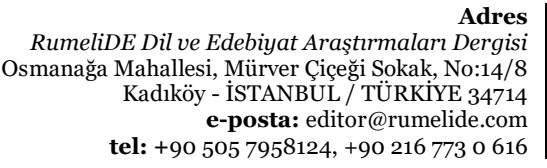

dres

RumeliDE Journal of Language and Literature Studies

Osmanağa Mahallesi, Mürver Çiçeği Sokak, No:14/8

Kadıköy - ISTANBUL / TURKEY 34714

e-mail: editor@rumelide.com,

phone: +90 $5057958124,+902167730616$ 
184 / RumeliDE Journal of Language and Literature Studies 2021.Ö10 (October)

An evaluation on the studies on determining the needs of learners in teaching Turkish as a foreign language / E. Kibar (pp. 180191)

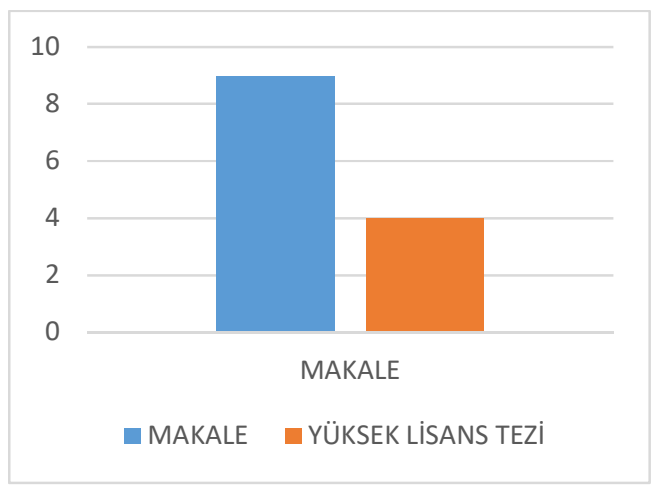

Grafik 1: Çalışmaların türlere göre dağılımı

Yukarıdaki grafikte görüldüğü gibi araştırmaya dahil edilen 13 çalışmanın 9’u makale, 4’ü yüksek lisans tezinden oluşmaktadır. Bu oranlara bakıldığında Türkçe’nin yabancı dil olarak öğretilmesinde öğrenenlerin dil ihtiyaçlarının belirlenmesine ilişkin yapılan çalışmaların çoğunluğunun makale olarak yazıldı ̆̆ını söyleyebiliriz.

\section{2. Çalışmaların "Yıllara göre dağılımı nasıldır?" sorusuna ilişkin bulgular}

Aşağıda Türkçenin yabancı dil olarak öğretilmesinde öğrenen ihtiyaçları tespiti çalışmalarının yıllara göre dağılımına ilişkin bilgiler verilmiştir.

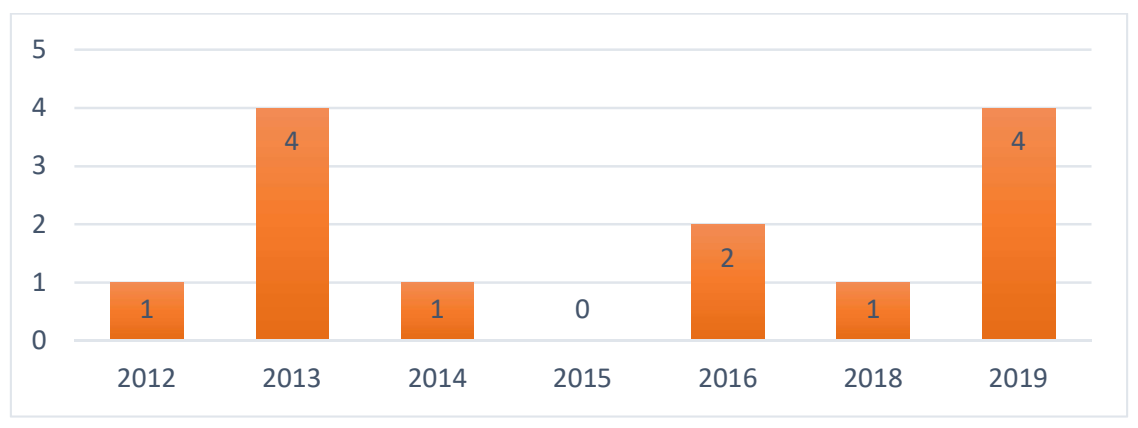

Grafik 2: Araştırmaların yıllara göre dağılımı

Grafik 2'ye göre Türkçe'nin yabancı dil olarak öğretilmesinde öğrenenlerin dil ihtiyaçlarının belirlenmesine ilişkin yapılan çalışmaların 2012-2019 yılları arasında yapıldığını görmekteyiz. Bu konuya ilişkin en fazla çalışma ise 2013 ve 2019 yllarında yapılmıştır.

\section{3. Çalışmaların "Hedef ülkelere göre ihtiyaç dağılımı nasıldır?" sorusuna ilişkin bulgular}

Aşağıda Türkçenin yabancı dil olarak öğretilmesinde öğrenen ihtiyaçları tespiti çalışmalarının hedef ülkelere göre dağılımına ilişkin bilgiler verilmiştir.

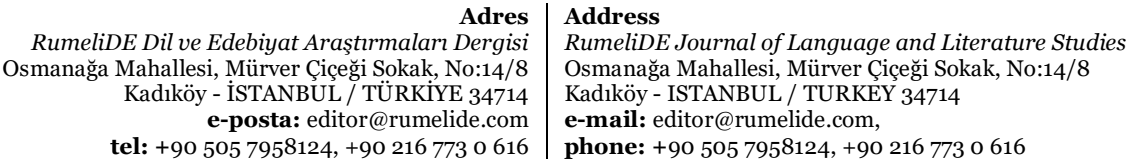




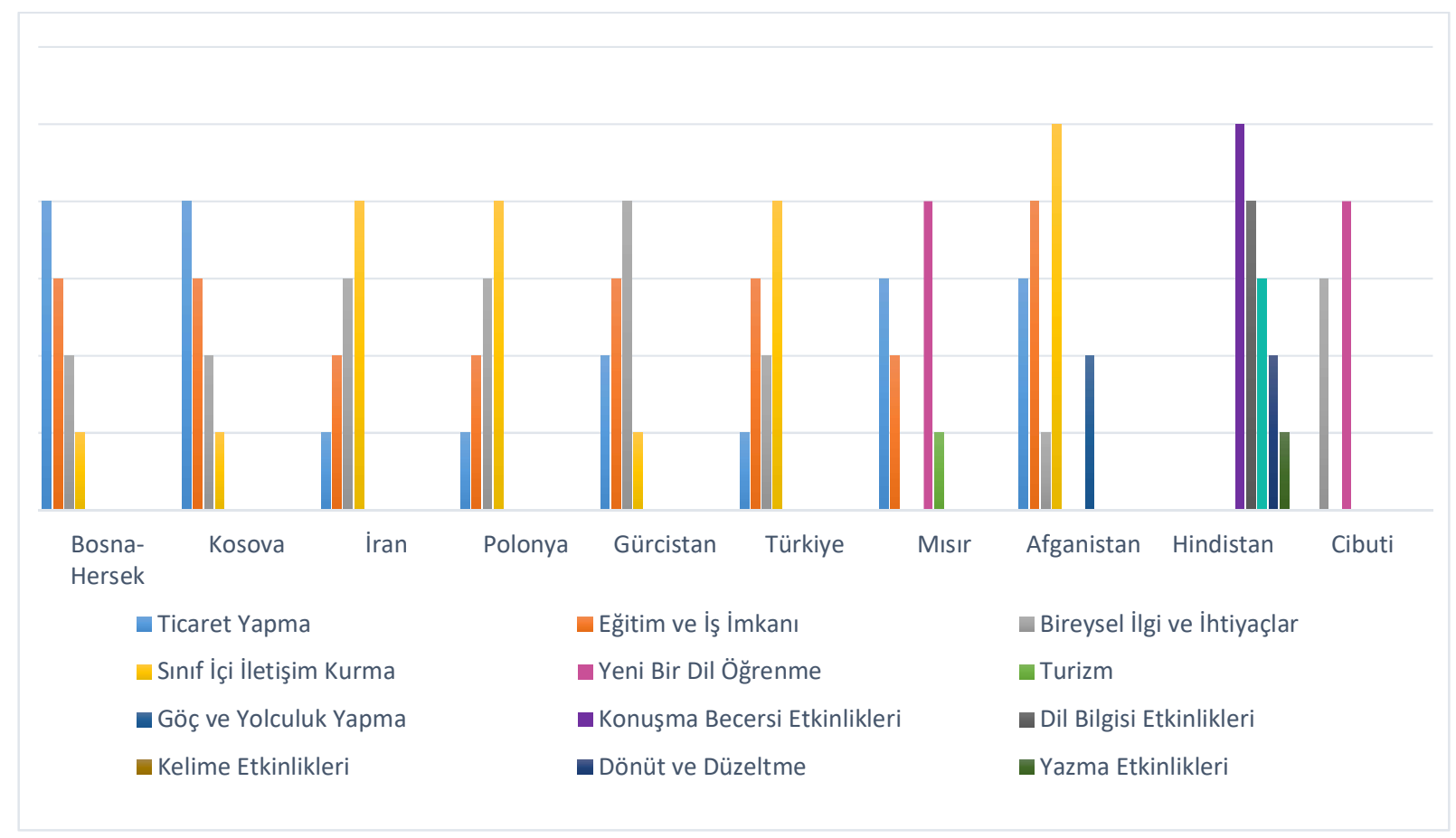

Grafik 3: Hedef ülkelerde tespit edilen ihtiyaçlar dağılımı

Yukarıdaki grafiğe bakıldığında 10 ülke (Bosna-Hersek, Kosova, İran, Polonya, Gürcistan, Türkiye, Mısır, Afganistan, Hindistan, Cibuti) üzerine ihtiyaç analizi yapıldığı görülmektedir. Bosna-Hersek ve Kosova'da Türkçeyi yabancı dil olarak öğrenen öğrencilerin dil ihtiyaçlarının aynı sıralamayı takip ettiğini görmekteyiz. Bu iki ülkede de dil ihtiyaçlarının başında “Ticaret Yapma” etmeninin ön plana çıtığını söyleyebiliriz. Bu durumun tam tersi olarak İran, Türkiye ve Polonya'ya bakıldığında "Ticaret Yapma” etmeni Türkçeyi yabancı dil olarak öğrenen öğrencilerin dil ihtiyaçlarında sonuncu sırada yer almaktadır. Bosna-Hersek, Kosova ve Gürcistan'daki öğrenenlerin dil ihtiyaçları arasında "Sınıf İçi İletişim Kurma” etmeni son sırada yer alırken İran, Polonya, Türkiye ve Afganistan'daki öğrenenlerin dil ihtiyaçları arasında ilk öncelik verdikleri faktör olmuştur.

"Eğitim ve İş İmkânı” etmeni Bosna-Hersek, Kosova, Gürcistan, Türkiye ve Afganistan'daki Türkçe öğrenenlerin dil ihtiyaçları arasında ikinci sırada karşımıza çıkarken İran, Polonya ve Mısır'da üçüncü sırada karşımıza çıkmaktadır.

Gürcistan'daki öğrenenler Türkçeyi en çok "Bireysel İlgi ve İhtiyaçları" için öğrenmek isterken bu etmen İran ve Polonya'daki öğrenenlerin dil ihtiyaçları arasında için ikinci sırada, Bosna-Hersek, Kosova ve Türkiye'deki öğrenenlerin dil ihtiyaçları arasında ise üçüncü sırada yer almaktadır.

Cibuti ve Mısır'a baktığımızda “Yeni Bir Dil Öğrenme” etmeninin ön plana çıktığı görmekteyiz. Mısır'da diğer ülkelerden farklı olarak öğrenenlerin dil ihtiyaçları arasında "Turizm Faktörü” yer alırken Afganistan'da "Göç ve Yolculuk Yapma” etmeninin yer aldığını görmekteyiz.

Hindistan'a baktığımızda diğer ülkelerden bambaşka bir tablo karşımıza çımaktadır. Hindistan'da gerçekleştirilen çalışmanın amacı öğrenenlerin neden Türkçe öğrendiklerini belirlemek değildir. Öğrenenlerin Türkçe öğrenirken hangi etkinliklere daha fazla ihtiyaç duyduğunu tespit etmektir.

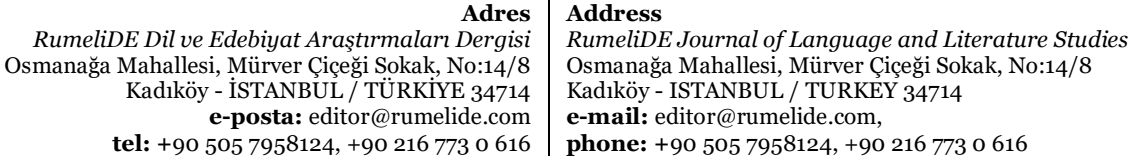


An evaluation on the studies on determining the needs of learners in teaching Turkish as a foreign language / E. Kibar (pp. 180191)

Çalışmadaki verilere göre Hindistan'daki öğrenenlerin sınıf içerisinde en çok ihtiyaç duyduğu etkinliklerin konuşma becerisi etkinlikleri olduğu tespit edilmiştir. Öğrencilerin konuşma becerisi etkinliklerinden sonra en fazla ihtiyaç duydukları konu ise dil bilgisi etkinlikleridir.

\section{4. Çalışmaların "Yöntem (odak, katılımcılar, veri toplama aracı ve analizi, veri toplama süreci) Bölümlerinin Tasarımı Nasıldır?” Sorusuna İlişkin Bulgular}

Aşağıda Türkçenin yabancı dil olarak öğretilmesinde öğrenen ihtiyaçları tespiti çalışmalarının yöntem bölümlerinin tasarımına ilişkin bilgiler verilmiştir.

\begin{tabular}{|c|c|c|c|c|}
\hline Araştırmacı & Odak & Katılımcılar & $\begin{array}{l}\text { Veri } \\
\text { Toplama } \\
\text { Araci ve } \\
\text { Analizi }\end{array}$ & Veri Toplama Süreci \\
\hline $\begin{array}{l}\text { Çalışkan ve } \\
\text { Bayraktar, } \\
2012 \text { (Makale) }\end{array}$ & $\begin{array}{l}\text { Yabancı dil } \\
\text { olarak } \\
\text { Türkçe } \\
\text { öğretimi, } \\
\text { Dil ihtiyaç } \\
\text { analizi }\end{array}$ & $\begin{array}{l}\text { Araştırmaya Kahire } \\
\text { Yunus Emre Türk } \\
\text { Kültür Merkezinde } 1 \\
\text { ila 4. Kurlarda Türkçe } \\
\text { eğitimi alan } 146 \text { kişi } \\
\text { katılım sağlamıştır. } \\
\text { Bu katılımcılardan } \\
\text { 144'ü Mısırlı, 1'i Rus, } \\
\text { 1'i ise Kazak'tır. }\end{array}$ & $\begin{array}{l}\text { İki bölümden } \\
\text { oluşan dil } \\
\text { ihtiyaç analizi } \\
\text { anketi }\end{array}$ & $\begin{array}{l}\text { Araştırmada kullanılan anket formu } \\
\text { Kahire Yunus Emre Türk Kültür } \\
\text { Merkezinde } 1 \text { ila 4. Kurlarda eğitim } \\
\text { gören öğrencilere uygulanmıştır. } \\
\text { Uygulama } 2012 \text { yılı Nisan ayı } \\
\text { içerisinde Türk dili okutmanı Semra } \\
\text { Bayraktar tarafından } \\
\text { gerçekleştirilmiştir. 1. Ve } 2 \text {. } \\
\text { kurlardaki öğrencilerin kolaylıkla } \\
\text { anlayabilmesi için anket iyi } \\
\text { derecede Arapça bilen okutmanlar } \\
\text { tarafindan Arapça olarak } \\
\text { çevrilmiştir. }\end{array}$ \\
\hline $\begin{array}{l}\text { İşcan, Şahin, } \\
\text { Kana ve } \\
\text { Koçer, 2013 } \\
\text { (Makale) }\end{array}$ & $\begin{array}{l}\text { Türkçe } \\
\text { öğretimi, } \\
\text { Yabancı dil } \\
\text { olarak } \\
\text { Türkçe } \\
\text { öğretimi, } \\
\text { İhtiyaç } \\
\text { algısı, Dil } \\
\text { becerileri }\end{array}$ & $\begin{array}{l}\text { Araşıırmaya } \\
\text { Hindistan'daki Nehru } \\
\text { Üniversitesinde } \\
\text { Türkçe öğrenen } \\
\text { yabancı uyruklu } 100 \\
\text { öğrenci katılım } \\
\text { sağlamıștır. } \\
\text { Katılımcılardan 34'ü } \\
\text { kız, 66'sı erkektir. }\end{array}$ & $\begin{array}{l}\text { Anket, Tekil } \\
\text { Tarama, } \\
\text { Betimsel } \\
\text { İstatistik }\end{array}$ & $\begin{array}{l}\text { Araştırmanın verileri Yıldız’ın } \\
\text { (2004) doktora tezi için geliştirdiği } \\
\text { anket aracılığıyla toplanmıştır. } \\
\text { Kullanılan anket Hindistan'da } \\
\text { Türkçe öğrenmek isteyen } 100 \\
\text { öğrenciye uygulanmıştır. }\end{array}$ \\
\hline $\begin{array}{l}\text { Tok ve Yıgın, } \\
2013 \\
\text { (Makale) }\end{array}$ & $\begin{array}{l}\text { Türkçenin } \\
\text { yabancı dil } \\
\text { olarak } \\
\text { öğretimi, } \\
\text { Motivasyon, } \\
\text { Bireysel } \\
\text { farklılıklar }\end{array}$ & $\begin{array}{l}\text { Araştırmaya } \\
\text { Çanakkale Onsekiz } \\
\text { Mart Üniversitesi } \\
\text { TÖMER'in Türkçe } \\
\text { kurslarında öğrenim } \\
\text { gören } 57 \text { yabancı } \\
\text { uyruklu öğgrenci } \\
\text { katılım sağlamıştır. }\end{array}$ & $\begin{array}{l}\text { Kişisel Bilgi } \\
\text { Formu, } \\
\text { Görüşme } \\
\text { Formu, İçerik } \\
\text { Analizi }\end{array}$ & $\begin{array}{l}\text { Araştırmada katılımcıların Türkçe } \\
\text { öğrenme nedenleri ülke, din ve dil } \\
\text { bilme durumlarına göre ele } \\
\text { alınacağı için ilk olarak kişisel bilgi } \\
\text { formu kullanılmıştır. Daha } \\
\text { sonrasında yabancı uyruklu } \\
\text { öğrencilerin Türkçe öğrenme } \\
\text { sebepleri yarı yapılandırılmış } \\
\text { görüş̧meler yapılarak ele alınmıştır. }\end{array}$ \\
\hline
\end{tabular}

Adres

RumeliDE Dil ve Edebiyat Araştırmaları Dergis Osmanağa Mahallesi, Mürver Çiçeği Sokak, No:14/8 Kadıköy - ISTANBUL / TÜRKIYE 34714 e-posta: editor@rumelide.com tel: +90 $5057958124,+902167730616$
Address

RumeliDE Journal of Language and Literature Studies Osmanağa Mahallesi, Mürver Çiçeği Sokak, No:14/8

Kadıköy - ISTANBUL / TURKEY 34714

e-mail: editor@rumelide.com,

phone: +90 $5057958124,+902167730616$ 


\begin{tabular}{|c|c|c|c|c|}
\hline $\begin{array}{l}\text { Koçer, } 2013 \\
\text { (Makale) }\end{array}$ & $\begin{array}{l}\text { İhtiyaç } \\
\text { analizi, } \\
\text { Durum } \\
\text { analizi, } \\
\text { Yabancı dil } \\
\text { olarak } \\
\text { Türkçe, } \\
\text { Program } \\
\text { geliştirme. }\end{array}$ & $\begin{array}{l}\text { Araştırmaya farklı } \\
\text { Arap ülkelerinden } \\
\text { gelmiş 20-29 yaşları } \\
\text { arasında } 33 \text { erkek, } 7 \\
\text { kadın öğrenci ve } \\
\text { TÖMER'de Türkçe } \\
\text { eğitimi veren iki } \\
\text { öğretmen katılım } \\
\text { sağlamıştır. }\end{array}$ & $\begin{array}{l}\text { Anket, } \\
\text { Gözlem, Açık- } \\
\text { uçlu sorular, } \\
\text { Görüşme, MS } \\
\text { Excel, } \\
\text { Betimsel } \\
\text { Analiz }\end{array}$ & 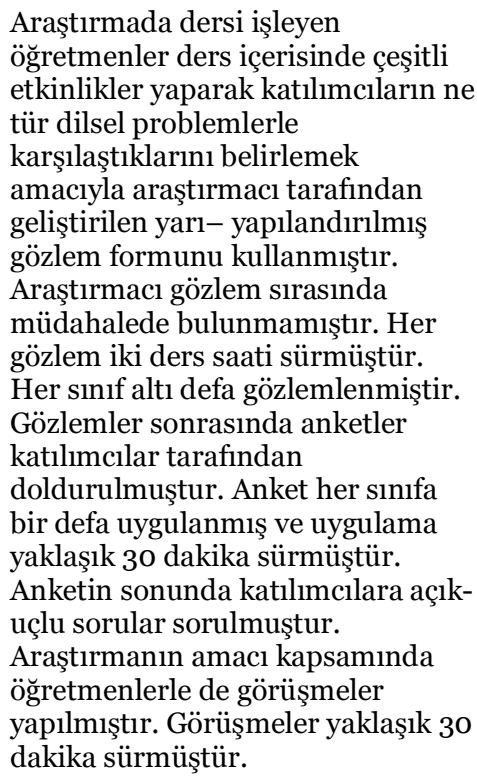 \\
\hline $\begin{array}{l}\text { Çalışkan ve } \\
\text { Çangal, } 2013 \\
\text { (Makale) }\end{array}$ & $\begin{array}{l}\text { Yabancilara } \\
\text { Türkçe } \\
\text { öğretimi, } \\
\text { Dil ihtiyaç } \\
\text { analizi }\end{array}$ & $\begin{array}{l}\text { Araştırmaya } \\
\text { Saraybosna ve } \\
\text { Foynitsa Yunus Emre } \\
\text { Türk Kültür } \\
\text { Merkezlerinde A1, } \\
\text { A2, ve B1 } \\
\text { seviyelerinde Türkçe } \\
\text { öğrenen } 286 \\
\text { kursiyerden } 168 \\
\text { kursiyer katılım } \\
\text { sağlamıştır. }\end{array}$ & $\begin{array}{l}\text { Araştırmacı } \\
\text { tarafindan } \\
\text { Türkçeye } \\
\text { uyarlanan Dil } \\
\text { İhtiyaç Analizi } \\
\text { Anketi, T-testi, } \\
\text { Varyans } \\
\text { analizi, F-testi }\end{array}$ & $\begin{array}{l}\text { Uygulama anketindeki yönergeleri } \\
\text { katılımcıların daha iyi } \\
\text { anlayabilmesi için Latin alfabesiyle } \\
\text { ana dilde düzenlenmiştir. } \\
\text { Uygulama, } 2013 \text { yılı Şubat ayı } \\
\text { içerisinde gerçekleştirilmiştir. }\end{array}$ \\
\hline $\begin{array}{l}\text { Boylu ve } \\
\text { Çangal, } 2014 \\
\text { (Makale) }\end{array}$ & $\begin{array}{l}\text { Yabancılara } \\
\text { Türkçe } \\
\text { öğretimi, } \\
\text { Dil ihtiyaç } \\
\text { analizi, Iran }\end{array}$ & $\begin{array}{l}\text { Araştırmaya Yunus } \\
\text { Emre Enstitüsü } \\
\text { Tahran Türk Kültür } \\
\text { Merkezinde Türkçe } \\
\text { öğrenen B ve C } \\
\text { seviyelerinde eğitim } \\
\text { alan 274 kursiyerden } \\
\text { 10o kursiyer katılım } \\
\text { sağlamıştır. Fakat } \\
\text { kursiyerlerden 4'ü } \\
\text { anketi eksik } \\
\text { doldurduğu sebebi ile } \\
\text { çalışmaya dahil } \\
\text { edilmemiştir. }\end{array}$ & $\begin{array}{l}\text { Çangal (2013) } \\
\text { tarafindan } \\
\text { Türkçeye } \\
\text { uyarlanan Dil } \\
\text { İhtiyaç Analizi } \\
\text { Anketi, } \\
\text { T- testi, Tek } \\
\text { yönlü varyans } \\
\text { analizi }\end{array}$ & $\begin{array}{l}\text { Araştırmada kullanılacak anketin } \\
\text { katılımcılar tarafından rahat } \\
\text { anlaşılabilmesi için çalışma B1.3 ve } \\
\text { üzeri kurlarda Türkçe ögrenmekte } \\
\text { olan kursiyerlerle } \\
\text { gerçekleştirilmiştir. Bununla } \\
\text { beraber ankette yer alan "Bosna- } \\
\text { Hersek" ifadesi "İran" şeklinde } \\
\text { değiştirilmiştir. Uygulama, } 2014 \text { yll } \\
\text { Eylül ayı içerisinde } \\
\text { gerçekleştirilmiştir. }\end{array}$ \\
\hline
\end{tabular}

Adres

RumeliDE Dil ve Edebiyat Araştırmaları Dergisi Osmanağa Mahallesi, Mürver Çiçeği Sokak, No:14/8 Kadıkö - ISTANBUL / TÜRKIYE 34714 e-posta: editor@rumelide.com tel: +90 $5057958124,+902167730616$
Address

RumeliDE Journal of Language and Literature Studies Osmanağa Mahallesi, Mürver Çiçeği Sokak, No:14/8

Kadıköy - ISTANBUL / TURKEY 34714

e-mail: editor@rumelide.com

phone: +90 5057958124 , +90 2167730616 
An evaluation on the studies on determining the needs of learners in teaching Turkish as a foreign language / E. Kibar (pp. 180191)

\begin{tabular}{|c|c|c|c|c|}
\hline $\begin{array}{l}\text { Başar ve } \\
\text { Akbulut, } 2016 \\
\text { (Makale) }\end{array}$ & $\begin{array}{l}\text { Dil ihtiyaç } \\
\text { analizi, } \\
\text { Yabancılara } \\
\text { Türkçe } \\
\text { öğretimi, } \\
\text { Gürcistan }\end{array}$ & $\begin{array}{l}\text { Araştırmaya } 2016 \\
\text { yllında Yunus Emre } \\
\text { Enstitüsü Tiflis Türk } \\
\text { Kültür Merkezinde } \\
\text { Türkçe öğrenen B ve } \\
\text { üzeri seviyelerdeki } 85 \\
\text { kursiyer katılım } \\
\text { sağlamıştır. }\end{array}$ & $\begin{array}{l}\text { Çangal (2013) } \\
\text { tarafindan } \\
\text { Türkçeye } \\
\text { uyarlanan Dil } \\
\text { İhtiyaç Analizi } \\
\text { Anketi, t- testi, } \\
\text { Tek yönlü } \\
\text { varyans analizi }\end{array}$ & $\begin{array}{l}\text { Araştırmanın verileri } 2016 \text { yılı Mart } \\
\text { ayında toplanmıştır. Ankette } 15 \\
\text { arka plan bilgisi ve } 27 \text { tane de } \\
\text { derecelendirme ölçütü bulunan } \\
\text { toplam } 42 \text { madde bulunmaktadır. } \\
\text { Yaklaşı olarak } 30 \text { dakikada } \\
\text { doldurulması ön görülmüştür. }\end{array}$ \\
\hline $\begin{array}{l}\text { Jilta, } 2016 \\
\text { (Yüksek } \\
\text { Lisans Tezi) }\end{array}$ & $\begin{array}{l}\text { Kosova } \\
\text { Yunus } \\
\text { Emre } \\
\text { Enstitüsü, } \\
\text { Yabancılara } \\
\text { Türkçe } \\
\text { Öğretimi, } \\
\text { Dil İhtiyaç } \\
\text { Analizi }\end{array}$ & $\begin{array}{l}\text { Araştırmaya Kosova } \\
\text { Yunus Emre } \\
\text { Enstitüsü'nde } \\
\text { öğrenim gören 17'si } \\
\text { kı, 43’ü erkek, } \\
\text { toplam 6o kursiyer } \\
\text { katılım sağlamıştır. }\end{array}$ & $\begin{array}{l}\text { Çangal (2013) } \\
\text { tarafindan } \\
\text { Türkçeye } \\
\text { uyarlanan Dil } \\
\text { İhtiyaç Analizi } \\
\text { Anketi, t-testi, } \\
\text { varyans analizi }\end{array}$ & $\begin{array}{l}\text { Araş̧ırmanın veri toplama aracı } \\
\text { olan anket } 2015 \text { yılında Kosova } \\
\text { Yunus Emre Enstitüsü’nde Prizren, } \\
\text { Priştine, İpek illerinde toplam } \\
\text { altmış kursiyere bizzat gidilerek } \\
\text { uygulanmıştır. }\end{array}$ \\
\hline $\begin{array}{l}\text { Phutkaradze, } \\
2018 \\
\text { (Yüksek } \\
\text { Lisans Tezi) }\end{array}$ & $\begin{array}{l}\text { Düzensiz } \\
\text { göçmenler, } \\
\text { Türkçe } \\
\text { öğretimi, } \\
\text { İhtiyaç } \\
\text { analizi }\end{array}$ & $\begin{array}{l}\text { Araştırmaya İstanbul, } \\
\text { Sakarya, Kocaeli, } \\
\text { Kayseri, Bursa } \\
\text { illerinde yabancı dil } \\
\text { olarak Türkçe } \\
\text { öğretimi yapan } 56 \\
\text { okutman, Sakarya ve } \\
\text { İstanbul'a geçici } \\
\text { olarak yerleşen } 85 \\
\text { düzensiz göçmen } \\
\text { katılım sağlamıştır. }\end{array}$ & $\begin{array}{l}\text { Anket, yarı } \\
\text { yapılandırılmış } \\
\text { görüşme, } \\
\text { içerik analizi }\end{array}$ & $\begin{array}{l}\text { Araştırmanın uygulaması sırasında } \\
\text { düzensiz göçmenlerin Türkçe } \\
\text { bilmedikleri dikkate alınarak } \\
\text { sorular okutmanlar tarafindan } \\
\text { İngilizce, Fransızca ve Arapçaya } \\
\text { çevrilmiştir. Araştırmadaki diğer bir } \\
\text { veri toplama aracı olan yarı } \\
\text { yapılandırılmış görüşmeler ise } \\
\text { farklı zamanlarda } 56 \text { öğretici ile } \\
\text { yapılarak kayda alınmıştır. }\end{array}$ \\
\hline $\begin{array}{l}\text { İpek ve Çelik, } \\
2019 \\
\text { (Makale) }\end{array}$ & $\begin{array}{l}\text { Yabancı dil } \\
\text { olarak } \\
\text { Türkçenin } \\
\text { öğretimi, } \\
\text { Dil ihtiyaç } \\
\text { analizi, } \\
\text { Polonya }\end{array}$ & $\begin{array}{l}\text { Araştırmaya } 2015 \\
\text { yılında Varşova } \\
\text { Yunus Emre } \\
\text { Enstitüsü'nde A1 ve } \\
\text { C1 seviyeleri arasında } \\
\text { Türkçe öğrenen } 109 \\
\text { kursiyer katılım } \\
\text { sağlamıştır. }\end{array}$ & $\begin{array}{l}\text { Çangal (2013) } \\
\text { tarafından } \\
\text { Türkçeye } \\
\text { uyarlanan Dil } \\
\text { İhtiyaç Analizi } \\
\text { Anketi,T- testi, } \\
\text { Tek yönlü } \\
\text { varyans analizi }\end{array}$ & $\begin{array}{l}\text { Araştırma, A1.1, A1.2, A2.1, A2.2, } \\
\text { B1.1, B1.2, B2.1, B2.2, C1.1, C1.2 } \\
\text { seviyelerinde Türkçe öğrenmekte } \\
\text { olan 109 kişi ile gerçekleştirilmiştir. } \\
\text { Bununla beraber anketteki bir } \\
\text { maddede "Bosna-Hersek" ifadesi } \\
\text { "Polonya" olarak değiştirilmiştir. } \\
\text { Uygulama, 2015 yılı Eylül ayı } \\
\text { içerisine gerçekleştirilmiştir. }\end{array}$ \\
\hline $\begin{array}{l}\text { Farzan, } 2019 \\
\text { (Yüksek } \\
\text { Lisans Tezi) }\end{array}$ & $\begin{array}{l}\text { Afganistan, } \\
\text { Yabancı Dil } \\
\text { Olarak } \\
\text { Türkçe } \\
\text { Öğretimi, } \\
\text { Dil İhtiyaç } \\
\text { Analizi }\end{array}$ & $\begin{array}{l}\text { Araştırmaya Kabil } \\
\text { Üniversitesi Türkoloji } \\
\text { Bölümü, Kabil } \\
\text { YETKM, İfsah } \\
\text { Yabancı Diller } \\
\text { Öğretim Merkezi ve } \\
\text { Star Enstitüsü’nde } \\
\text { farklı kurlarda } \\
\text { Türkçe öğrenen } \\
\text { toplam 147 öğrenci } \\
\text { katılım sağlamıştır. }\end{array}$ & $\begin{array}{l}\text { Çangal (2013) } \\
\text { tarafindan } \\
\text { Türkçeye } \\
\text { uyarlanan Dil } \\
\text { İhtiyaç Analizi } \\
\text { Anketi, T-testi, } \\
\text { tek yönlü } \\
\text { varyans analizi }\end{array}$ & $\begin{array}{l}\text { Anket, } 2018 \text { yılının A ğustos ayı } \\
\text { içerisinde Kabil Üniversitesi } \\
\text { Türkoloji Bölümü, Kabil YETKM, } \\
\text { İfsah ile Star özel ve bağımsız dil } \\
\text { öğretim merkezlerinde Türkçe } \\
\text { öğrenenlere bizzat gidilerek } \\
\text { uygulanmıştır. Anket, önceden } \\
\text { Afganistan'ın resmi dillerinden } \\
\text { birisi olan ve yaygın bir şekilde } \\
\text { kullanılan Farsçaya çevrilmiştir. } \\
\text { Türkçeyi yüksek seviyede bilen } \\
\text { öğrencilere Türkçe anketi, Türkçesi } \\
\text { yeterli olmayanlara ise Farsça } \\
\text { anketi dağıtılmıştır. }\end{array}$ \\
\hline
\end{tabular}

Adres RumeliDE Dil ve Edebiyat Araştırmaları Dergisi Osmanağa Mahallesi, Mürver Ciçeği Sokak, No:14/8 Kadıköy - ISTANBUL / TÜRKIYE 34714 e-posta: editor@rumelide.com tel: +90 $5057958124,+902167730616$
Address

RumeliDE Journal of Language and Literature Studies Osmanağa Mahallesi, Mürver Çiçeği Sokak, No:14/8

Kadıköy - ISTANBUL / TURKEY 34714

e-mail: editor@rumelide.com

phone: +90 $5057958124,+902167730616$ 


\begin{tabular}{|c|c|c|c|c|}
\hline $\begin{array}{l}\text { Deliktaş, } 2019 \\
\text { (Yüksek } \\
\text { Lisans Tezi) }\end{array}$ & $\begin{array}{l}\text { İstanbul, } \\
\text { Yabancı Dil } \\
\text { Olarak } \\
\text { Türkçe } \\
\text { Öğretimi, } \\
\text { Dil İhtiyaç } \\
\text { analizi }\end{array}$ & $\begin{array}{l}\text { Araştırmaya İstanbul } \\
\text { Üniversitesi Dil } \\
\text { Merkezinde Türkçe } \\
\text { öğrenen } 125 \text { kursiyer } \\
\text { katılım sağlamıştır. }\end{array}$ & $\begin{array}{l}\text { Çangal (2013) } \\
\text { tarafindan } \\
\text { Türkçeye } \\
\text { uyarlanan Dil } \\
\text { İhtiyaç Analizi } \\
\text { Anketi, t-testi, } \\
\text { tek yönlü } \\
\text { varyans analizi }\end{array}$ & $\begin{array}{l}\text { Araştırmanın verileri } 2019 \text { yılının } \\
\text { Nisan ayı içerisinde bir haftalık } \\
\text { sürede toplanmıştır. İstanbul } \\
\text { Üniversitesi Dil Merkezindeki } \\
\text { Türkçe okutmanlarına, anket ile } \\
\text { ilgili bilgilendirme yapıldıktan } \\
\text { sonra anketler öğrencilere, } \\
\text { derslerine giren okutmanlar } \\
\text { aracıllğıyla ulaştırılmış̧ırır. Farklı } \\
\text { seviyelerdeki öğrencilerin anketteki } \\
\text { soruları anlayabilmeleri için A1 ve } \\
\text { A2 seviyelerindeki öğrencilere } \\
\text { İngilizce anket dağıtılmış olup } \\
\text { B1,B2 ve C1 seviyelerindeki } \\
\text { öğrencilere ise seçme hakkı } \\
\text { verilmiştir. }\end{array}$ \\
\hline $\begin{array}{l}\text { Sayar, } 2019 \\
\text { (Makale) }\end{array}$ & $\begin{array}{l}\text { Yabancı Dil } \\
\text { Olarak } \\
\text { Türkçe } \\
\text { Öğretimi, } \\
\text { Dil İhtiyaç } \\
\text { analizi, } \\
\text { Cibuti }\end{array}$ & $\begin{array}{l}\text { Araştırmaya Cibuti } \\
\text { Üniversitesi'nde } \\
\text { Türkçe öğrenen } 7 \text { kız, } \\
8 \text { erkek öğrenci } \\
\text { katılım sağlamıştır. }\end{array}$ & $\begin{array}{l}\text { Görüşme } \\
\text { Formu, } \\
\text { Betimsel içerik } \\
\text { analizi }\end{array}$ & $\begin{array}{l}\text { Araştırmanın verileri, 2016-2017 } \\
\text { eğitim öğretim yılında Cibuti } \\
\text { Üniversitesi’nde Türkçeyi } \\
\text { yabancı dil olarak öğrenen } \\
\text { öğrencilerin, öğretim süreci } \\
\text { boyunca neler hissettiklerini ve } \\
\text { onların öznel ihtiyaçlarını } \\
\text { belirlemek amacıyla yarı- } \\
\text { yapılandırılmış görüşmeler ile } \\
\text { toplanmıştır. Görüşme formunda, } \\
\text { öğrenicilerin “Türkçe öğrenirken } \\
\text { yaşadıkları zorluklar, bu } \\
\text { zorluklar karşında baş etme } \\
\text { şekilleri ve Türkçeyi öğrenme } \\
\text { sebepleri” konularını ele alan } \\
\text { sorulara yer verilmiştir. }\end{array}$ \\
\hline
\end{tabular}

Tablo 1: Araştırmaların odak, katılımcılar, veri toplama aracı ve analizi, veri toplama sürecine yönelik bulgular

Yukarıdaki tablo incelendiğinde 13 araştırmanın odak noktasında yabancı dil olarak Türkçe öğretimi ve dil ihtiyaç analizi olduğunu görülmektedir. Araştırmalar Türkçe öğretim merkezlerinde ve yurtdışında farklı ülkelerde yer alan Yunus Emre Enstitülerinde gerçekleştirilmiştir. Araştırmaların veri toplama araçları incelendiğinde 6 çalışmada, Iwai ve diğerlerinin (1998) Japanese Language Needs Analysis isimli çalışmalarında kullandıkları ölçeğin, Çangal (2013) tarafından Türkçeye uyarlanan dil ihtiyaç analizi anketinin kullanıldığı görülürken, 4 çalışmada görüşme ve yarı yapılandırılmış anket kullanılmıştır.

\section{Sonuç}

Türkçenin yabancı dil olarak öğretiminde öğrenen ihtiyaçlarının belirlenmesine ilişkin yapılan çalışmaları analiz etmeyi amaçlayan bu çalışmada konuyla alakalı 13 çalışma yayın yılı, araştırma türleri, dil ihtiyaçlarının ülkelere göre hangi alt boyutlarda yoğunlaştığı, örneklem büyüklüğü, veri toplama araçları ve veri analiz teknikleri açısından incelenmiştir.

Türkiye'de yapılan dil ihtiyaç analizi çalışmaları araştırma türlerine göre incelendiğinde 9 çalışmanın makale türünde, 4 çalışmanın ise yüksek lisans tezi olarak yazıldığı görülmüştür.

Araştırmaya dahil edilen çalışmaların yayın yılına göre dağılımları incelendiğinde araştırmaların 2012 2019 yılları arasında yayınlandığını tespit edilmiştir. 2012 yılından önce veya 2019 yılından sonra bu

Adres Address

RumeliDE Dil ve Edebiyat Araştırmaları Dergisi RumeliDE Journal of Language and Literature Studies Osmanağa Mahallesi, Mürver Çiçeği Sokak, No:14/8 $\quad$ Osmanağa Mahallesi, Mürver Çiçeği Sokak, No:14/8 Kadıköy - İSTANBUL / TÜRKIYE 34714 Kadıköy - ISTANBUL / TURKEY 34714 e-posta: editor@rumelide.com e-mail: editor@rumelide.com, tel: +90 $5057958124,+90216773$ o 616 phone: +90 505 7958124, +90 216773 o 616 
konu ile alakalı literatürde herhangi bir çalışmaya rastlanamamıştır. Türkiye'de dil ihtiyaç analizi çalışmalarının 2012 ylında başlamasının sebebini bu yılda Türkiye'de yüksek öğretim kurumlarında öğretim gören yabancı öğrenci sayısının artması olarak gösterebiliriz. DEİK’in 2013 yllındaki raporunda görüldüğü gibi 2006 yılında Türkiye’de yüksek öğretim kurumlarında öğretim gören yabancı öğrenci sayısı 2012 yılında iki katına çıkmıştır. Bu oran artarak devam etmektedir. Öğrenci sayısının artarak devam etmesi Türkiye'nin siyasi konumundaki gelişmelerden kaynaklı olabileceği düşünülmektedir. Yabancı dil olarak Türkçe'nin yaygınlaşması program geliştirmenin birinci basamağı olan dil ihtiyaç analizi ihtiyacını da beraberinde getirmiştir.

Bölgesel bazda yapılan çalışmaların ilki Çalışkan ve Bayraktar (2012) tarafından Kahire Yunus Emre Türk Kültürü Merkezinde gerçekleştirilen araştırmadır. Araştırmada ilk defa bölgesel bazda Türkçeyi yabancı dil olarak öğrenen yetişkinlerin dil ihtiyaçları belirlemeye yönelik analiz yapılması amaçlanmıştır.

Çalışmaların hedef ülkelere göre dağılımları incelendiğinde sonuç olarak İran, Türkiye, Afganistan ve Polonya'da Türkçeyi yabancı dil olarak öğrenen öğrencilerin dil ihtiyaçlarının başında "Sınıf İçi İletişim Kurma” amacı yer alırken Bosna-Hersek, Kosova ve Gürcistan'daki öğrencilerin "Sınıf İçi İletişim Kurma” ihtiyacının en son sırada yer aldığı tespit edilmiştir. İran, Hindistan ve Polonya'da yapılan çalışmalarda dil ihtiyaç analizi sonuçlarına göre konuşma becerisinin kazanımının zorluğu ve bu becerinin kazandırılması önemli olduğu sonucuna varılmıştır. Çünkü, konuşma becerisi dil öğrenmenin en önemli göstergelerinden birisidir. Yeni öğrenilen bir yabancı dilde de en zor kazanılan becerilerden olduğu için öğrenciler bu beceriye daha fazla ihtiyaç duymuşlardır (İşcan vd., 2013). Bosna-Hersek ve Kosova'da yapılan çalışmada Türkçe öğrenen kursiyerlerin "Ticaret Yapma" ihtiyaçları ön plana çlkarken İran, Polonya ve Türkiye'de yapılan çalışmalarda Türkçe öğrenen kursiyerler "Ticaret Yapma" ihtiyacını en sonda tercih ettikleri görülmektedir. Aynı zamanda İran ve Polonya'da yapılan araştırmalardaki ihtiyaç analizi sıralamasının aynı olduğu dikkat çekmiştir. Bu sonuç bize İran'da Türkçe öğretimi ile Polonya'da Türkçe öğretimi süreçlerinin aynı olduğunu göstermektedir.

Araştırmaların veri toplama araçları incelendiğinde 2013 yılından sonra yapılan çalışmaların çoğunda Çangal (2013) tarafından Türkçeye uyarlanan dil ihtiyaç analizi anketinin kullanıldığını görmekteyiz.

Öğrencilerin dil ihtiyaçları, beklentilerine, yaşadıkları yaşantıya veya ülkelerine göre farklılık gösterebilmektedir. Bu sebeple ülkemizde Türkçe öğreten kurumlarda ve farklı ülkelerde Türkçenin yabancı dil olarak öğretilmesine ilişkin ihtiyaç analizi çalışmalarının nitelikli eğitim ve ihtiyaca göre öğretim açısından daha fazla yapılması gerekmektedir.

\section{Kaynakça}

Başar, U. \& Akbulut, E. (2016). Yabancılara Türkçe Öğretiminde Öğrenen İhtiyaçlarının Belirlenmesi: Yunus Emre Enstitüsü Tiflis Türk Kültür Merkezi Örneği. Uluslararası Türkçe Edebiyat Kültür Eğitim (TEKE) Dergisi, 5 (2), o-o. DOI: 10.7884/teke.673

Boylu, E. \& Çangal, Ö. (2014). Yabancllara Türkçe Öğretiminde Dil İhtiyaç Analizi: İran Örneği. International Journal of Language Academy, 2 (5), 127-127. https://doi.org/10.18033/IJLA.152

Çalışkan, N. \& Çangal, Ö. (2013). Yabancılara Türkçe Öğretiminde Dil İhtiyaç Analizi: Bosna-Hersek Örneği. Abant İzzet Baysal Üniversitesi Eğitim Fakültesi Dergisi, 13(2), 310- 334.

DEIK (2013). Uluslararası Yüksek Öğretim ve Türkiye’nin Konumu, Eğitim Ekonomisi Konseyi Raporu. Istanbul. https://www.deik.org.tr/uploads/uluslararasi-yuksekogretim-hareketliligi-ve-turkiyenin-konumu- raporu 2.pdf.

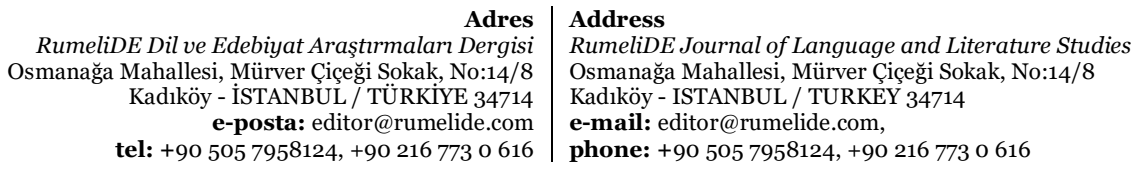


Deliktaş, A. (2019). Yabancı Dil Olarak Türkçe Öğretiminde Dil İhtiyaç Analizi: İstanbul Örneği. Yayınlanmış Yüksek Lisans Tezi. İstanbul.

Demir, D. (2017). Uluslararası Öğrencilerin Akademik Türkçe İhtiyaçları. Yayınlanmış Doktora Tezi. Hacettepe Üniversitesi. Ankara.

Farzan, E. (2019). Afganistan'da Türkçe Öğrenen Öğrencilere Yönelik Dil İhtiyaç Analizi. Yayınlanmış Yüksek Lisans Tezi. Sakarya.

İpek, S. (2013). Yeni Hitit Kitabıyla Yabancılara Türkçe Öğretiminde Polonya'da Karşılaşılan Sorunlar. VI. Uluslararası Dünya Dili Türkçe Sempozyumu. Uludă̆ Üniversitesi. Bursa.

İpek, S. \& Çelik, N. (2019). Yabancı Dil Olarak Türkçe Öğretiminde Dil İhtiyaç Analizi: Polonya Örneği. Aydın TÖMER Dil Dergisi, 4 (2), 101-136.

İşcan, A. Vd. (2013). Yabancı Dil Olarak Türkçe Öğrenen Öğrencilerin İhtiyaç Algıları: Betimsel Bir Durum Çalışması. International Journal of Social Science. (6)

Jilta, G. (2016). Yabancı Dil Olarak Türkçe Öğretiminde Öğrenene Yönelik Dil İhtiyaç Analizi: Kosova Örneği. Yayınlanmış Yüksek Lisans Tezi. İstanbul.

Koçer, Ö. (2013). Program Geliştirmenin İlk Basamağı: Yabancı Dil Olarak Türkçe Öğretiminde İhtiyaç ve Durum Analizi. Eğitim ve Bilim, 38(169).

Phutkaradze, M. (2018). Düzensiz Göçmenlerin Dil İhtiyaç Analizi ve Bir Program Önerisi. Yayınlanmış Yüksek Lisans Tezi. Sakarya.

Sak, R., Şahin Sak, İ. T., Öneren Şendil, Ç., \& Nas, E. (2021). Bir araştırma yöntemi olarak doküman analizi. Kocaeli Üniversitesi Eğitim Dergisi, 4(1), 227-25o. http://doi.org/10.3340o/kuje.843306

Sayar, E. (2019). Yabancı Dil Olarak Türkçe Öğrenme Nedenlerine Yönelik Bir İhtiyaç Analizi: Cibuti Örneği. Hacettepe Üniversitesi Yabancı Dil Olarak Türkçe Araştırmaları Dergisi, (5), 95-108.

Tok, M. \& Yıgın, M. (2013). Yabancı Uyruklu Öğrencilerin Türkçe Öğrenme Nedenlerine İlişkin Bir Durum Çalışması. Dil ve Edebiyat Eğitimi Dergisi, (8), 132-147.

Yağmur, K. (2006). Batı Avrupa'da Türkçe Öğretiminin Sorunları ve Çözüm Önerileri. Dil Dergisi, (134), $31-48$.

Yaman, H. \& Dağtaş, A. (2015). İngiltere'deki İki Dilli Türk Çocuklarına Türkçe Öğreten Öğretmenlerin İhtiyaç Analizi: Swot Analizi Örneği. Uluslararası Sosyal ve Eğitim Bilimleri Dergisi, 2(4), 47-82. DOI: $10.20860 /$ ijoses.53160

Yılmaz, F. \& Konyar, M. (2017). Türkçenin Yabancı Dil Olarak Öğretiminde Akademik Türkçe İhtiyaç Analizi. International Journal of Language Academy (5).

RumeliDE Dil ve Edebiyat Araştırmaları Dergisi Osmanağa Mahallesi, Mürver Çiçeği Sokak, No:14/8 Kadıköy - İSTANBUL / TÜRKIYE 34714 e-posta: editor@rumelide.com tel: +90 $5057958124,+902167730616$
Address

RumeliDE Journal of Language and Literature Studies

Osmanağa Mahallesi, Mürver Çiçeği Sokak, No:14/8

Kadıköy - ISTANBUL / TURKEY 34714

e-mail: editor@rumelide.com,

phone: +90 5057958124, +90 2167730616 